\title{
Postharvest Life Extension of Fresh-Cut Mango (Mangifera indica cv. Fa-Lun) Using Chitosan and Carboxymethyl Chitosan Coating
}

\author{
Duangjai Noiwan $^{1,2}$, Kiattisak Sutenan ${ }^{3}$, Chatchai Yodweingchai ${ }^{3}$ \& Pornchai Rachtanapun ${ }^{1,3,4}$ \\ ${ }^{1}$ Postharvest Technology Research Center, Faculty of Agriculture, Chiang Mai University, Chiang Mai, \\ Thailand \\ ${ }^{2}$ Graduate School, Chiang Mai University, Chiang Mai, Thailand \\ ${ }^{3}$ Division of Packaging Technology, Faculty of Agro-Industry, Chiang Mai University, Chiang Mai, Thailand \\ ${ }^{4}$ Center of Excellence in Materials Science and Technology, Chiang Mai University, Chiang Mai, Thailand \\ Correspondence: Pornchai Rachtanapun, Division of Packaging Technology, Faculty of Agro-Industry, Chiang \\ Mai University, Chiang Mai 50100, Thailand. Tel: 666-3549-2556. E-mail: pornchai.r@cmu.ac.th
}

Received: April 29, 2018

doi:10.5539/jas.v10n8p438
Accepted: June 9, 2018 Online Published: July 15, 2018

URL: https://doi.org/10.5539/jas.v10n8p438

\begin{abstract}
Postharvest life extension of fresh-cut mango (Mangifera indica cv. Fa-Lun) using chitosan and carboxymethyl chitosan $(\mathrm{CMCH})$ coating was studied. Fresh-cut mango was treated with chitosan and carboxymethyl chitosan solution of $0.5-1.5 \% \mathrm{w} / \mathrm{v}$, after that fresh-cut mango was placed on foam tray, over-wrapped with PVC film and then stored at $6{ }^{\circ} \mathrm{C}$. Weight loss, texture analysis, soluble solid content, color and sensory quality were evaluated. The shelf life of non-coated fresh-cut mango was only 2 days while that of fresh-cut mango coated with chitosan and carboxymethyl chitosan was 4 and 6 days, respectively. Effect of chitosan concentration on quality of fresh-cut mango was significantly different but of carboxmethyl chitosan concentration was not. In this study, Coating with carboxymethyl chitosan could extend shelf life of fresh-cut mango by delayed flesh browning which correlated to the sensory score.
\end{abstract}

Keywords: chitosan, carboxymethyl chitosan, coating, fresh-cut mango, shelf life

\section{Introduction}

Seafood industry in Thailand has brought a considerable amount of income. However, the scraps after seafood processing, mainly the shells of crustaceans and squids are priceless. Many researchers try to use these scraps as raw materials for the production of chitin polymer. Chitin is one of the most abundant natural polymers next to cellulose, found particularly in the shell of crustaceans such as shrimps, crabs and insects and also cell wall of fungi (Kittur et al., 2002; Abdou et al., 2008; Elieh-Ali-Komi \& Hamblin, 2016; Philibert et al., 2017). Chitosan is produced by chemical deacetylation of chitin. It is a biopolymer with low toxicity and had been used in various applications. In biomedical and pharmaceutical applications, chitosan film is used as drug-releasing-control agent (Shu \& Zhu, 2002; Islam et al., 2017). In waste water management, chitosan can adsorb toxin and humic acid that can be got rid out of water later. Chitosan is also used as a supplementary food (Yinsong et al., 2007; de Abreu and Campana-Filho, 2009; Gómez-Mascaraque et al., 2016). In agricultural application, chitosan coating have been widely used on fruit and vegetable mainly with the purpose of providing it with a modified atmosphere, reducing gas transfer, retarding moisture and flavor loss, delaying color changes, and improving the general appearance of the produce through storage time. Pen and Jiang (2003) studied the storage life of fresh-cut Chinese water chestnut using chitosan coating and found that the treatment could inhibit the activities of polyphenol oxidase, peroxidase and phenylalanine ammonia lyase (PAL). They also found that chitosan coating delayed the decreasing of anthocyanin and inhibited polyphenol oxidase activity. Chien et al. (2007) studied the effect of chitosan coating on quality and storage life of fresh-cut mango and found that the treatment could preserve quality and prolong the storage life of the product. Vargas et al. (2009) studied the effect of chitosan coating in combination with vacuum condition on the storage of fresh-cut carrot and found that the treatment could reduce water permeability and color change. However, there are also problems in using chitosan. The solubility of chitosan is restricted to only acid solution (de Abreu and Campana-Filho, 2009; Ryu et al., 2015; Wang et al., 2015; Rui et al., 2017) and it represents a serious drawback to many of its potential 
applications, especially the odor of acid on the product which is not accepted by the consumers. Therefore, the chemical modifications of chitosan structure are normally designed to increase the polymer solubility in a wide $\mathrm{pH}$ range by the carboxymethylation of chitosan through the direct alkylation (El-Sherbiny, 2009). de Abreu and Campana-Filho (2009) studied the synthetic pathway of carboxymethyl chitosan and the influences of various variables (the proportion of water/isopropanol, chloroacetic acid content, temperature and reaction duration) on the substitution degree of carboxymethyl chitosan. In the synthesis of carboxymethyl chitosan or sodium carboxymethyl chitosan, it started with chloroacetic acid as a reactant (etherifying agent) in alkaline condition (pre-alkalized chitosan) with alcohol solvent. The carboxymethylation reaction of chitosan occurred at the site of amino group and hydroxyl group of the polymer. Due to the protonation and highly alkaline properties of amino group in chitosan, these made it soluble in only acid aqueous solution $(\mathrm{pH}<6.5)$ which restricted its applications Making chitosan derivatives could solve this solubility problem (Miao et al., 2008; An et al., 2009; de Abreu and Campana-Filho et al., 2009). At present, there are various applications in using carboxymethyl chitosan as edible coating because of its solubility property. Zhou et al. (2008) coated carboxymethyl chitosan in pear and found the reducing of respiration and weight loss, but the efficacy was still less than when coated with shellac. The carboxymethyl chitosan had a good effect on decreasing malondialdehyde content and delaying spoilage of peach fruits suggesting their possible use as preservative and antioxidant coating (Elbarbarya \& Mostafa, 2014). $\mathrm{Wu}$ and Yang (2015) suggested that brassinolide and carboxymethyl chitosan coating has the potential to maintain the quality parameters of asparagus spears and extend its storage life. Benhabiles et al. (2013) concluded that the effect of a chitosan coating seems to be comparable to an N,O-carboxymethyl chitosan coating in improving postharvest preservation of tomato fruit. There has little report about using carboxymethyl chitosan for coating fresh-cut product. This research aimed to study the effect of carboxymethyl chitosan $(\mathrm{CMCH})$ as coating agent for fresh-cut mango and compare the efficacy of carboxymethyl chitosan to chitosan at various concentrations on the quality and storage life of fresh-cut mango.

\section{Materials and Method}

\subsection{Materials}

Mango (Mangifera indica cv. Fa-Lun) was taken for the study. A commercial chitosan with a degree of deacetylation of $85 \%$ (Ta Ming Enterprisrs Co., Ltd., Thailand), isopropyl alcohol (IPA) (Northern Chemical and Glassware, Thailand), chloroacetic acid $\left(\mathrm{CH}_{2} \mathrm{CICO}_{2} \mathrm{H}\right)$ (Sigma-Aldrich, Germany), acetic acid $\left(\mathrm{CH}_{3} \mathrm{COOH}\right)$ (LAB-SCAN, Thailand), ethanol $\left(\mathrm{C}_{2} \mathrm{H}_{6} \mathrm{O}\right)$ (Northern Chemical and Glassware, Thailand), methanol (Northern Chemical and Glassware, Thailand), sodium hydroxide (NaOH) (LAB-SCAN, Thailand) monochloroacetic acid (MCA) (Sigma-Aldrich, Germany), and distilled water were used to carboxymethyl chitosan and chitosan coating preparation.

\subsection{Coating Preparation}

\subsubsection{Carboxymethyl Chitosan (CMCH) Synthesis}

Carboxymethyl chitosan was synthesized according to Tantala et al. (2012a, 2012b). The chitosan powder was suspended in a solution (NaOH: IPA: distilled-water) for $1 \mathrm{~h}$. The appropriate amount of monochloroacetic acid was added into the solution for $30 \mathrm{~min}$. The mixture was continuously reacted at $50{ }^{\circ} \mathrm{C}$ for $4 \mathrm{~h}$. The solid phase was separated from the liquid phase and then suspended in $95 \%$ methanol. The reaction was stopped by adding glacial acetic acid and the $\mathrm{pH}$ was adjusted to neutrality. After that, the solid was washed in $70 \%$ ethanol to desalt and filtered and then rinsed once with $95 \%$ ethanol. The carboxymethyl chitosan powder was dried in a hot air oven at $50{ }^{\circ} \mathrm{C}$ overnight.

\subsubsection{Preparation of Carboxymethyl Chitosan and Chitosan Solution}

$\mathrm{CMCH}(0.5,1.0$ and $1.5 \% \mathrm{w} / \mathrm{v})$ solution was prepared by dissolving in distilled water at $50-80{ }^{\circ} \mathrm{C}$. To chitosan solutions $(0.5,1.0$ and $1.5 \% \mathrm{w} / \mathrm{v})$, chitosan was dissolved in $0.5 \%$ acetic acid.

\subsection{Minimally Processed Mangoes}

Mango fruits were washed, peeled and cut into strip pieces. Fresh-cut mangoes were coated with $0.5,1.0,1.5 \%$ $\mathrm{w} / \mathrm{v}$ chitosan and $0.5,1.0,1.5 \% \mathrm{w} / \mathrm{v}$ carboxymethyl chitosan compared with control treatment (non-coated). The samples were placed in the foam tray and wrapping with PVC film. Finally, all samples were stored at $6 \pm 2{ }^{\circ} \mathrm{C}$. Five pieces per treatment were used to study each quality parameter every two days.

\subsection{Quality Assessment}

\subsubsection{Weight Loss}

Weight loss of all samples was individually monitored every two day with an analytical balance. 
The results were expressed as the percentage loss of initial weight.

\subsubsection{Firmness}

Flesh firmness was evaluated at 3 points using a texture analyzer (Model Instron 5565, USA) with a $6 \mathrm{~mm}$ cylindrical probe into the sample at the test speed of $1 \mathrm{~mm} / \mathrm{sec}$ and the depth of $5 \mathrm{~mm}$.

\subsubsection{Soluble Solid Contents (SSC)}

SSC of each mango juice sample was performed using a hand refractometer (ATAGO Model N-1E, Japan) in triplicate and expressed as a percentage.

\subsubsection{Color Measurement}

Mango strip color was measured by Color Reader (Minolta Model CR-200, Japan) and recorded using the CIE- $L^{*} a^{*} b^{*}$ uniform color space. Each sample was taken from three different points on the strip.

\subsubsection{Sensory Evaluation}

The postharvest life of measurements was determined by sensory evaluations using a descriptive test (9-point hedonic scale), where, $1=$ Dislike Extremely, $2=$ Dislike Very Much, $3=$ Dislike Moderately, $4=$ Dislike Slightly, $5=$ Neither Like nor Dislike, $6=$ Like Slightly, $7=$ Like Moderately, $8=$ Like Very Much and 9= Like Extremely. Fifty semi-trained panelists were chosen to determine the fresh-cut mango quality aspects such as general appearance, test, and aroma (off-flavor) attribute of the given sample. Fifty semi-trained panelists evaluated the fresh-cut mango quality.

\subsection{Statistical Analysis}

SPSS software (Version 11, SPSS Inc., Chicago, IL) was used to analyze the data. One-way analysis of variance (ANOVA) was carried out using Duncan's multiple range test $(p \leq 0.05)$.

\section{Results and Discussion}

\subsection{Weight Loss}

Weight loss of chitosan and carboxymethyl chitosan-coated fresh-cut mango is shown in Figure 1. The longer period of storage, the higher weight loss occurred. The rate of weight loss at lower concentration of coating material was greater than weight loss at higher concentration with no statistical difference $(p<0.05)$ between treatments. The longer period of storage, the higher weight loss occurred, in accordance with firmness decreased in every treatment. The decrease of fruit firmness related with the changing of plant metabolism and water loss. Loss of weight in fresh produce is mostly due to the loss of water caused by transpiration and respiration processes (Zhou et al., 2008; Noiwan et al., 2017). The use of edible coating was effective in decreasing weight loss along storage. According to Chien et al. (2007) who studied the effect of chitosan coating on quality and storage life of fresh-cut mango and found that chitosan coating could protect weight loss of the product. In a similar study, Ferrari et al. (2013) confirmed a reduction of weight loss in fresh-cut melon coated with pectin edible coatings.

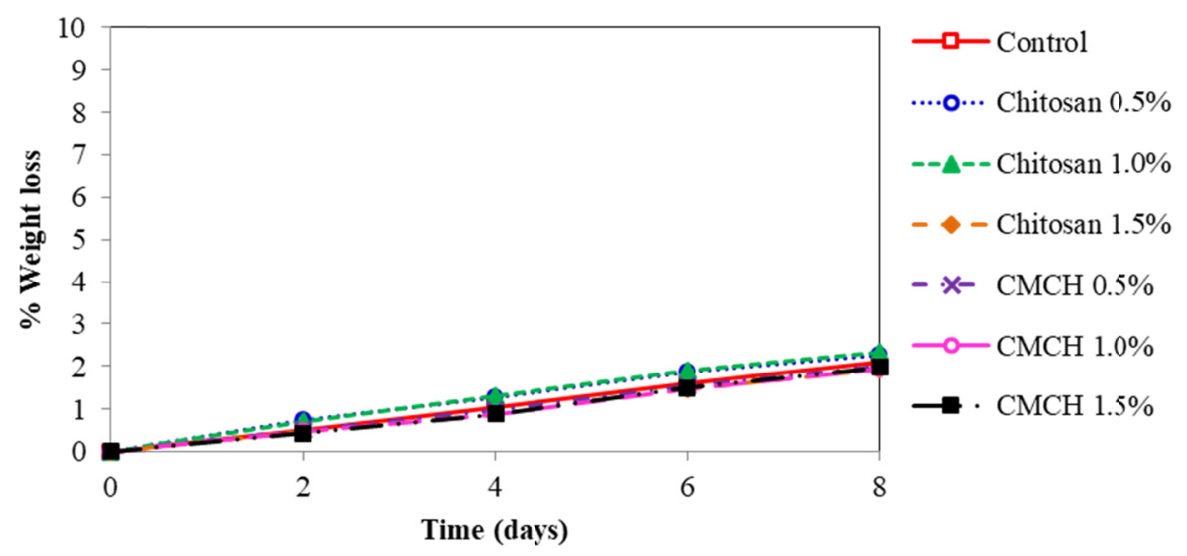

Figure 1. Weight loss of chitosan and carboxymethyl chitosan-coated fresh-cut mango 


\subsection{Firmness}

Table 1 shows the firmness of chitosan and carboxymethyl chitosan-coated fresh-cut mango. Flesh firmness decreased with storage period in every treatment with no statistical difference $(\mathrm{p}<0.05)$ between treatments, in accordance with weight loss percentage in Figure 1. The degradation of the cell wall constituents and polysaccharides by the action of pectin esterase and polygalacturonase on the solubilization of pectin substrates were causes of fruit softens (Yashoda et al., 2007; Razzaq et al., 2013). The firmness of fresh-cut mango significantly reduced throughout storage life, but this decrease was more pronounced for chitosan and non-coat sample from the fourth day, meaning that the $\mathrm{CMCH}$ was able to maintain flesh texture. According to Chiumarelli et al. (2011) in fresh-cut mangoes coated with sodium alginate or cassava starch, higher firmness preservation in coated samples along the postharvest time.

Table 1. Firmness of chitosan and carboxymethyl chitosan-coated fresh-cut mango

\begin{tabular}{llllll}
\hline \multirow{2}{*}{ Treatment } & \multicolumn{5}{c}{ Firmness (N) } \\
\cline { 2 - 6 } & Day 0 & Day 2 & Day 4 & Day 6 & Day 8 \\
\hline Control & $73.064 \pm 3.63^{\mathrm{aC}}$ & $60.910 \pm 6.39^{\mathrm{aB}}$ & $54.420 \pm 2.21^{\mathrm{aA}}$ & $56.213 \pm 2.80^{\mathrm{abA}}$ & $53.274 \pm 2.10^{\mathrm{aA}}$ \\
Chitosan 0.5\% & $73.064 \pm 3.63^{\mathrm{aC}}$ & $64.040 \pm 5.22^{\mathrm{bB}}$ & $56.422 \pm 1.53^{\mathrm{bcA}}$ & $58.618 \pm 2.66^{\mathrm{bA}}$ & $55.789 \pm 1.93^{\mathrm{aA}}$ \\
Chitosan 1.0\% & $73.064 \pm 3.63^{\mathrm{aB}}$ & $54.013 \pm 1.27^{\mathrm{aA}}$ & $52.533 \pm 1.19^{\mathrm{aA}}$ & $53.730 \pm 3.75^{\mathrm{aA}}$ & $54.925 \pm 3.22^{\mathrm{aA}}$ \\
Chitosan 1.5\% & $73.064 \pm 3.63^{\mathrm{aD}}$ & $54.451 \pm 3.28^{\mathrm{aAB}}$ & $52.114 \pm 2.06^{\mathrm{aA}}$ & $58.110 \pm 3.97^{\mathrm{bC}}$ & $56.168 \pm 1.81^{\mathrm{aBC}}$ \\
CMCH 0.5\% & $73.064 \pm 3.63^{\mathrm{aC}}$ & $55.802 \pm 1.09^{\mathrm{aA}}$ & $58.449 \pm 2.75^{\mathrm{cdB}}$ & $54.945 \pm 2.51^{\mathrm{abA}}$ & $54.943 \pm 1.72^{\mathrm{aA}}$ \\
CMCH 1.0\% & $73.064 \pm 3.63^{\mathrm{aC}}$ & $56.761 \pm 2.01^{\mathrm{aA}}$ & $60.957 \pm 3.19^{\mathrm{eB}}$ & $54.921 \pm 2.56^{\mathrm{abA}}$ & $55.819 \pm 3.72^{\mathrm{aA}}$ \\
CMCH 1.5\% & $73.064 \pm 3.63^{\mathrm{aB}}$ & $56.137 \pm 3.47^{\mathrm{aA}}$ & $60.654 \pm 1.94^{\mathrm{deA}}$ & $56.944 \pm 3.82^{\mathrm{abA}}$ & $55.855 \pm 4.06^{\mathrm{aA}}$ \\
\hline
\end{tabular}

Note. ${ }^{\mathrm{A}, \mathrm{B}, \mathrm{C}}$ : Different letters in the same row indicate significant differences among formulation $(p<0.05) ;{ }^{\mathrm{a}, \mathrm{b}, \mathrm{c}}$ : Different letters in the same column indicate significant differences among formulation $(p<0.05)$.

\subsection{Soluble Solid Contents (SSC)}

The effect of chitosan and carboxymethyl chitosan coating on soluble solid contents of fresh-cut mango is shown in Table 2. The SSC of fresh-cut mango was about $7.4 \%$ (day 0 ), and it slightly increase until the end of storage (day 8). Soluble solid contents increased with storage period. The result was in accordance with Srinivasa et al. (2002) who also reported the increasing in soluble solid contents in mango with storage period.

Table 2. SSC of chitosan and carboxymethyl chitosan-coated fresh-cut mango

\begin{tabular}{llllll}
\hline \multirow{2}{*}{ Treatment } & \multicolumn{5}{c}{ Soluble Solid Contents (\%) } \\
\cline { 2 - 6 } & Day 0 & Day 2 & Day 4 & Day 6 & Day 8 \\
\hline Control & $7.47 \pm 0.17^{\mathrm{aA}}$ & $7.12 \pm 1.26^{\mathrm{aA}}$ & $8.24 \pm 0.28^{\mathrm{aAB}}$ & $9.09 \pm 0.46^{\mathrm{bB}}$ & $8.74 \pm 0.07^{\mathrm{bB}}$ \\
Chitosan 0.5\% & $7.47 \pm 0.17^{\mathrm{aA}}$ & $7.97 \pm 0.36^{\mathrm{aAB}}$ & $8.64 \pm 0.88^{\mathrm{aB}}$ & $8.37 \pm 0.58^{\mathrm{abAB}}$ & $8.18 \pm 0.53^{\mathrm{aAB}}$ \\
Chitosan 1.0\% & $7.47 \pm 0.17^{\mathrm{aA}}$ & $8.13 \pm 0.62^{\mathrm{aAB}}$ & $8.04 \pm 0.37^{\mathrm{aAB}}$ & $8.08 \pm 0.37^{\mathrm{aAB}}$ & $8.21 \pm 0.08^{\mathrm{aB}}$ \\
Chitosan 1.5\% & $7.47 \pm 0.17^{\mathrm{aA}}$ & $8.12 \pm 1.06^{\mathrm{aA}}$ & $8.57 \pm 0.54^{\mathrm{aA}}$ & $8.19 \pm 0.49^{\mathrm{aA}}$ & $7.98 \pm 0.07^{\mathrm{aA}}$ \\
CMCH 0.5\% & $7.47 \pm 0.17^{\mathrm{aA}}$ & $7.66 \pm 0.47^{\mathrm{aAB}}$ & $7.94 \pm 0.08^{\mathrm{aBC}}$ & $8.30 \pm 0.03^{\mathrm{abC}}$ & $8.18 \pm 0.18^{\mathrm{aC}}$ \\
CMCH 1.0\% & $7.47 \pm 0.17^{\mathrm{aA}}$ & $7.48 \pm 0.02^{\mathrm{aA}}$ & $8.48 \pm 0.68^{\mathrm{aB}}$ & $8.31 \pm 0.32^{\mathrm{abB}}$ & $7.79 \pm 0.30^{\mathrm{aAB}}$ \\
CMCH 1.5\% & $7.47 \pm 0.17^{\mathrm{aA}}$ & $7.88 \pm 0.62^{\mathrm{aA}}$ & $8.18 \pm 0.65^{\mathrm{aA}}$ & $8.26 \pm 0.46^{\mathrm{aA}}$ & $7.89 \pm 0.19^{\mathrm{aA}}$ \\
\hline
\end{tabular}

Note. ${ }^{\mathrm{A}, \mathrm{B}, \mathrm{C}}$ : Different letters in the same row indicate significant differences among formulation $(p<0.05) ;{ }^{\mathrm{a}, \mathrm{b}, \mathrm{c}}$ : Different letters in the same column indicate significant differences among formulation $(p<0.05)$.

\subsection{Color Changes}

The effect of chitosan and carboxymethyl chitosan coating on color measurement of fresh-cut mango is shown in Figure 2. Light value $\left(\mathrm{L}^{*}\right)$ tended to decrease in all treatments, especially in non-coating group. Coating with carboxymethyl chitosan gave the best result in delaying the decrease of $L^{*}$ value, followed by coating with chitosan as shown in Figure 2a. The different concentrations of chitosan gave significantly different results in $\mathrm{L}^{*}$ value while this difference was not found in carboxymethyl chitosan treatments. The effect of chitosan and carboxymethyl chitosan coatings on color measurement on green to red color ( $\mathrm{a}^{*}$ value) of fresh-cut mango is 
shown in Figure $2 b$ which indicated that the longer storage period, the higher $a^{*}$ value in all treatments. Coating with carboxymethyl chitosan gave the best result in delaying the increasing of $\mathrm{a}^{*}$ value, followed by coating with chitosan and non-coating, respectively. In comparing the effect of various concentrations of coating agents on color measurement $\left(\mathrm{L}^{*}, \mathrm{a}^{*}\right.$ and $\left.\mathrm{b}^{*}\right)$, it was found that different chitosan concentrations gave significantly different results. Coating chitosan at 0.5 and $1.0 \% \mathrm{w} / \mathrm{v}$ could prevent color change better than at $1.5 \% \mathrm{w} / \mathrm{v}$ while no statistical differences in color change in carboxymethyl chitosan treatment at various concentrations. Light value ( $\left.\mathrm{L}^{*}\right)$ tended to decrease in all treatments, especially in non-coating group. Coating with carboxymethyl chitosan gave the best result in delaying the decrease of $\mathrm{L}^{*}$ and $\mathrm{a}^{*}$ value, followed by coating with chitosan. Generally, the $\mathrm{a}^{*}$ value related with browning reaction caused by enzymatic oxidation on phenolic compounds, especially peroxidase and polyphenol oxidase (Jiang, 2000). Apai et al. (2009) reported that coating longan with chitosan inhibited PPO activity and delayed browning reaction during storage. Mostly, browning on the surface of fresh-cut mango is caused by gaseous oxygen. The edible coatings are a good barrier to carbon dioxide and oxygen, reducing respiration rates and delaying browning in fresh-cut fruits (Bico et al. 2009; Qi et al. 2011). At high concentration of chitosan, excessive thick film occurred and changed the respiration metabolism in fresh-cut mango tissues from aerobic to anaerobic condition and made the tissue's surface browning rapidly. However, coating with carboxymethyl chitosan gave the best result in delay the color change in this experiment. Because a high polar property of carboxymethyl chitosan, caused by the replacement of non-water soluble amino group by carboxyl group and the occurred of negative charge of hydroxyl group in chitosan polymer, made more solubility of carboxymethyl chitosan than chitosan (Chen \& Park, 2003; Liang et al., 2004; de Abreu \& Campana-Filho, 2009; El-Sherbiny, 2009). A high polar of carboxymethyl chitosan gave more cohesion force between molecules and prevent the permeated of oxygen gas than.

(a)

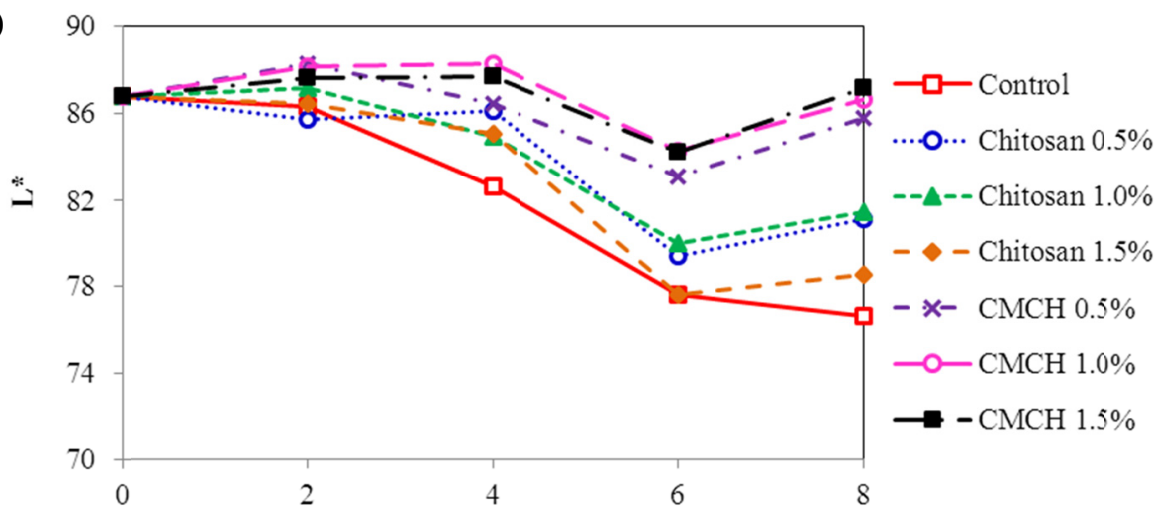

(b)

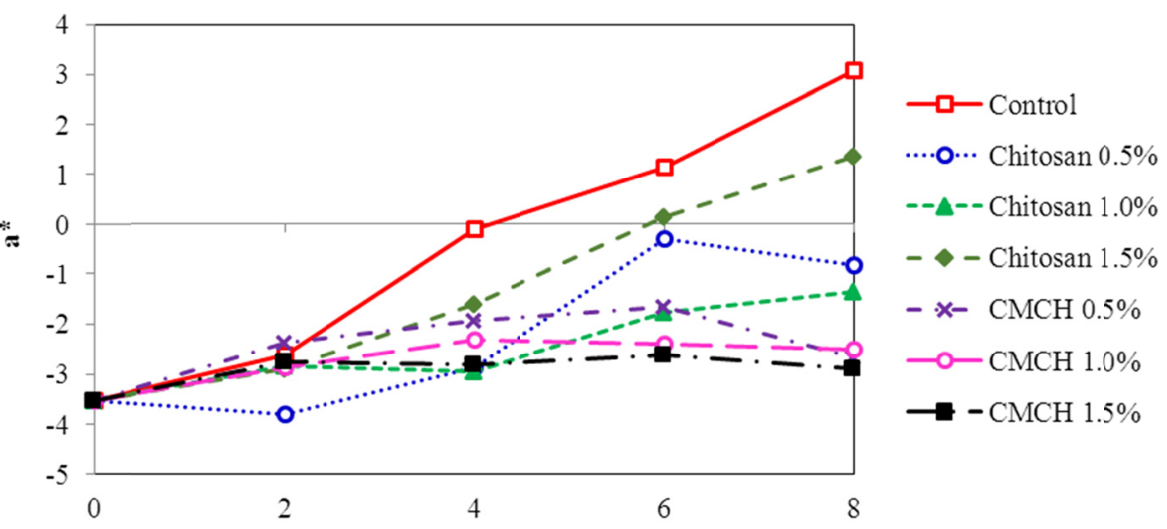




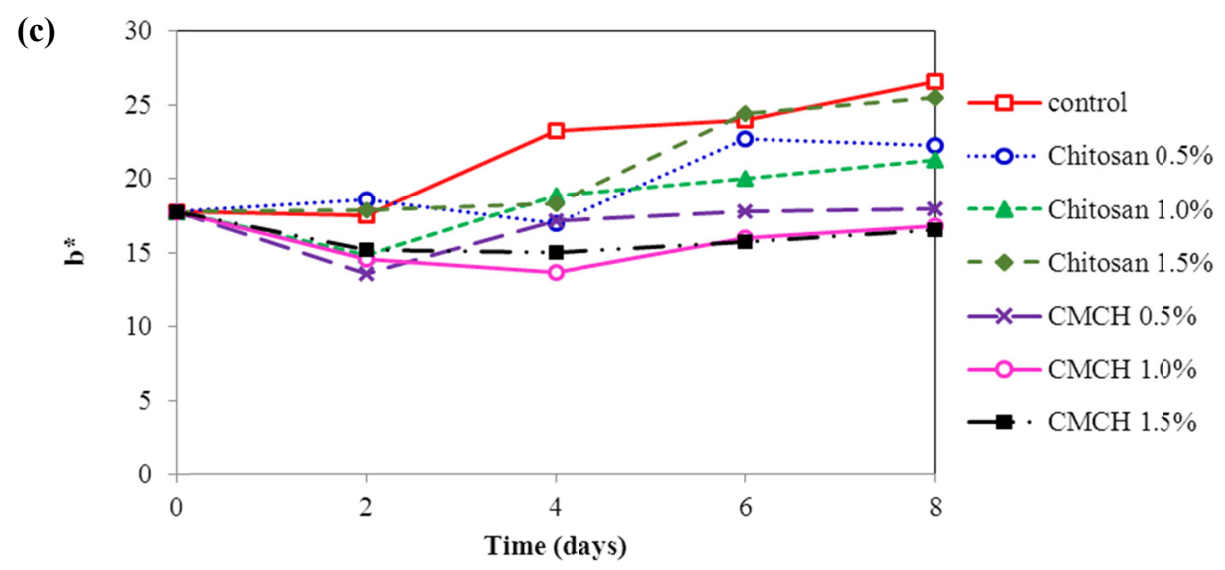

Figure 2. Color change (a) L*, (b) a* and (c) b* of chitosan and carboxymethyl chitosan-coated fresh-cut mango

\subsection{Sensory Evaluation}

The longer period of storage, the lower sensory score in non-coated group was found. Coating with carboxymethyl chitosan gave higher sensory score than coating with chitosan (Figure 3). The result was related with color measurement, indicating that consumers use color as the first index in evaluating the overall quality of fresh-cut mango. The color changed in Figure 2 was related to sensory score, especially browning index. Higher $\mathrm{a}^{*}$ value in non-coated group in Figure $2 \mathrm{~b}$ at the $4^{\text {th }}$ day of storage related with the low acceptance score of the consumers. Coating with chitosan delayed the change of $\mathrm{a}^{*}$ value when compared to non-coated group, with low acceptance score at the $6^{\text {th }}$ day of storage. Coating with carboxymethyl chitosan gave the best result in delaying the change of $a^{*}$ value, making the end up of acceptance score at day $8^{\text {th }}$ of storage. Coating with carboxymethyl chitosan gave higher sensory score than coating with chitosan. The result was related with color measurement, indicating that consumers use color as the first index in evaluating the overall quality of fresh-cut mango. Higher a* value in non-coated group related with the low acceptance score of the consumers. Coating with chitosan delayed the change of $\mathrm{a}^{*}$ value when compared to non-coated group. The retaining in surface color by chitosan was caused by its properties in anti-oxidation, microbial inhibition and oxygen protection (Fan et al., 2009). The inhibition browning effect as provided by edible coating is observed in many coated fresh-cut fruits, such as papaya (Tapia et al., 2008), banana (Bico et al., 2009), and apple (Qi et al., 2011).

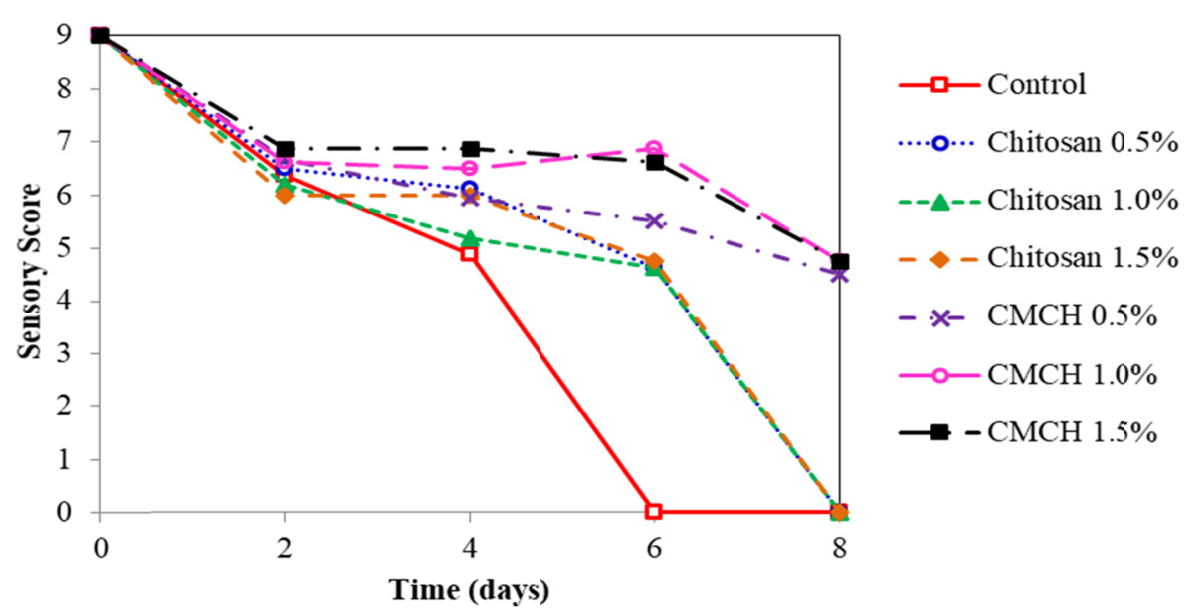

Figure 3. Sensory score of chitosan and carboxymethyl chitosan-coated fresh-cut mango

\section{Conclusion}

Shelf life of non-coating fresh-cut mango was 2 days while coating with chitosan and carboxymethyl chitosan could extend the shelf life of fresh-cut mango to 4 and 6 days, respectively. Fresh-cut mango coating with 
carboxymethyl chitosan gave the best physical qualities (color). The carboxymethyl chitosan could delay browning reaction better than non-coating and coating with chitosan.

\section{Acknowledgements}

This research is financially supported by office of the Higher Education Commission and the Postharvest Technology Innovation Center, Commission on Higher Education, Bangkok, Thailand. We would like to thank the Center of Excellence in Materials Science and Technology for financial support under the administration of the Materials Science Research Center, Faculty of Science, Chiang Mai University. The authors express no conflict of interest and no competing financial interest.

\section{References}

Abdou, E. S., Nagy, K. S. A., \& Elsabee, M. Z. (2008). Extraction and characterization of chitin and chitosan from local sources. Bioresource Technology, 99(5), 1359-1367. https://doi.org/10.1016/j.biortech.2007. 01.051

An, N. T., Thien, D. T., Dong, N. T., \& Dung, P. L. (2009). Water-soluble N-carboxymethylchitosan derivatives: Preparation, characteristics and its application. Carbohydrate Polymers, 75(3), 489-497. https://doi.org/ 10.1016/j.carbpol.2008.08.017

Apai, W., Sardsud, V., Boonprasom, P., \& Sardsud, U. (2009). Effects of chitosan and citric acid on pericarp browning and polyphenol oxidase activity of longan fruit. Songklanakarin Journal of Science and Technology, 31(6), 621-628.

Benhabiles, M. S., Tazdait, D., Abdi, N., Lounici, H., Drouiche, N., Goosen, M. F. A., \& Mameri, N. (2013). Assessment of coating tomato fruit with shrimp shell chitosan and N,O-carboxymethyl chitosan on postharvest preservation. Journal of Food Measurement and Characterization, 7(2), 66-74. https://doi.org/ 10.1007/s11694-013-9140-9

Bico, S. L. S., Raposo, M. F. J., Morais, R. M. S. C., \& Morais, A. M. M. B. (2009). Combined effects of chemical dip and/or carrageenan coating and/or controlled atmosphere on quality of fresh-cut banana. Food Control, 20(5), 508-514. https://doi.org/10.1016/j.foodcont.2008.07.017

Chen, X. G., \& Park, H. J. (2003). Chemical characteristics of O-carboxymethyl chitosans related to the preparation conditions. Carbohydrate Polymers, 53(4), 355-359. https://doi.org/10.1016/S0144-8617(03) 00051-1

Chien, P. J., Sheu, F., \& Lin, H. R. (2007). Quality assessment of low molecular weight chitosan coating on sliced red pitayas. Journal of Food Engineering, 79(2), 736-740. https://doi.org/10.1016/j.jfoodeng.2006. 02.047

Chien, P. J., Sheu, F., \& Yang, F. H. (2007). Effects of edible chitosan coating on quality and shelf life of sliced mango fruit. Journal of Food Engineering 78(1), 225-229. https://doi.org/10.1016/j.jfoodeng.2005.09.022

Chiumarelli, M., Ferrari, C. C., Sarantópoulos, C. I. G. L., \& Hubinger, M. D. (2011). Fresh cut 'Tommy Atkins' mango pre-treated with citric acid and coated with cassava (Manihot esculenta $\mathrm{Crantz}$ ) starch or sodium alginate. Innovative Food Science \& Emerging Technologies, 12(3), 381-387. https://oi.org/10.1016/ j.ifset.2011.02.006

de Abreu, F. R., \& Campana-Filho, S. P. (2009). Characteristics and properties of carboxymethylchitosan. Carbohydrate Polymers, 75(2), 214-221. https://doi.org/10.1016/j.carbpol.2008.06.009

Elbarbary, A. M., \& Mostafa, T. B. (2014). Effect of $\gamma$-rays on carboxymethyl chitosan for use as antioxidant and preservative coating for peach fruit. Carbohydrate Polymers, 104, 109-117. https://oi.org/10.1016/ j.carbpol.2014.01.021

Elieh-Ali-Komi, D., \& Hamblin, M. R. (2016). Chitin and Chitosan: Production and Application of Versatile Biomedical Nanomaterials. International Journal of Advanced Research, 4(3), 411-427.

El-Sherbiny, I. M. (2009). Synthesis, characterization and metal uptake capacity of a new carboxymethyl chitosan derivative. European Polymer Journal, 45(1), 199-210. https://doi.org/10.1016/j.eurpolymj.2008. 10.042

Fan, W., Sun, J., Chen, Y., Qiu, J., Zhang, Y., \& Chi, Y. (2009). Effects of chitosan coating on quality and shelf life of silver carp during frozen storage. Food Chemistry, 115(1), 66-70. https://doi.org/10.1016/j.foodchem. 2008.11 .060 
Ferrari, C. C., Sarantópoulos, C. I. G. L., Carmello-Guerreiro, S. M., \& Hubinger, M. D. (2013). Effect of Osmotic Dehydration and Pectin Edible Coatings on Quality and Shelf Life of Fresh-Cut Melon. Food and Bioprocess Technology, 6(1), 80-91. https://doi.org/10.1007/s11947-011-0704-6

Gómez-Mascaraque, L. G., Sanchez, G., \& López-Rubio, A. (2016). Impact of molecular weight on the formation of electrosprayed chitosan microcapsules as delivery vehicles for bioactive compounds. Carbohydrate Polymers, 150, 121-130. https://doi.org/10.1016/j.carbpol.2016.05.012

Islam, S., Bhuiyan, M. A. R., \& Islam, M. N. (2017). Chitin and Chitosan: Structure, Properties and Applications in Biomedical Engineering. Journal of Polymers and the Environment, 25(3), 854-866. https://doi.org/ 10.1007/s10924-016-0865-5

Jiang, Y. (2000). Role of anthocyanins, polyphenol oxidase and phenols in lychee pericarp browning. Journal of the Science of Food and Agriculture, 80(3), 305-310. https://doi.org/10.1002/1097-0010(200002)80:3<305:: AID-JSFA518>3.0.CO;2-H

Kittur, F. S., Harish Prashanth, K. V., Udaya Sankar, K., \& Tharanathan, R. N. (2002). Characterization of chitin, chitosan and their carboxymethyl derivatives by differential scanning calorimetry. Carbohydrate Polymers, 49(2), 185-193. https://doi.org/10.1016/S0144-8617(01)00320-4

Liang, P., Zhao, Y., Shen, Q., Wang, D., \& Xu, D. (2004). The effect of carboxymethyl chitosan on the precipitation of calcium carbonate. Journal of Crystal Growth, 261(4), 571-576. https://oi.org/10.1016/ j.jcrysgro.2003.03.001

Miao, J., Chen, G., Gao, C., \& Dong, S. (2008). Preparation and characterization of N,O-carboxymethyl chitosan/Polysulfone composite nanofiltration membrane crosslinked with epichlorohydrin. Desalination, 233(1), 147-156. https://doi.org/10.1016/j.desal.2007.09.037

Noiwan, D., Suppakul, P., Joomwong, A., Uthaibutra, J., \& Rachtanapun, P. (2017). Kinetics of mango fruits (Mangifera indica cv. 'Nam Dok Mai Si Thong') quality changes during storage at various temperatures. Journal of Agricultural Science, 9(6), 199-212. https://doi.org/10.5539/jas.v9n6p199

Pen, L. T., \& Jiang, Y. M. (2003). Effects of chitosan coating on shelf life and quality of fresh-cut Chinese water chestnut. LWT-Food Science and Technology, 36(3), 359-364. https://doi.org/10.1016/S0023-6438(03) 00024-0

Philibert, T., Lee, B. H., \& Fabien, N. (2017). Current Status and New Perspectives on Chitin and Chitosan as Functional Biopolymers. Applied Biochemistry and Biotechnology, 181(4), 1314-1337. https://doi.org/ 10.1007/s12010-016-2286-2

Qi, H., Hu, W., Jiang, A., Tian, M., \& Li, Y. (2011). Extending shelf-life of Fresh-cut 'Fuji' apples with chitosan-coatings. Innovative Food Science \& Emerging Technologies, 12(1), 62-66. https://doi.org/ 10.1016/j.ifset.2010.11.001

Razzaq, K., Khan, A. S., \& Shahid, M. (2013). Ripening period influences fruit softening and antioxidative system of 'Samar Bahisht Chaunsa' mango. Scientia Horticulturae, 160, 108-114. https://doi.org/10.1016/ j.scienta.2013.05.018

Rui, L., Xie, M., Hu, B., Zhou, L., Saeeduddin, M., \& Zeng, X. (2017). Enhanced solubility and antioxidant activity of chlorogenic acid-chitosan conjugates due to the conjugation of chitosan with chlorogenic acid. Carbohydrate Polymers, 170, 206-216. https://doi.org/10.1016/j.carbpol.2017.04.076

Ryu, J. H., Hong, S., \& Lee, H. (2015). Bio-inspired adhesive catechol-conjugated chitosan for biomedical applications: A mini review. Acta Biomaterialia, 27, 101-115. https://doi.org/10.1016/j.actbio.2015.08.043

Shu, X. Z., \& Zhu, K. J. (2002). The influence of multivalent phosphate structure on the properties of ionically cross-linked chitosan films for controlled drug release. European Journal of Pharmaceutics and Biopharmaceutics, 54(2), 235-243. https://doi.org/10.1016/S0939-6411(02)00052-8

Srinivasa, P., Baskaran, R., Ramesh, M., Harish Prashanth, K., \& Tharanathan, R. (2002). Storage studies of mango packed using biodegradable chitosan film. European Food Research and Technology, 215(6), 504-508. https://doi.org/10.1007/s00217-002-0591-1

Tantala, J., Rachtanapun, C., \& Rachtanapun, P. (2012a). Effect of Molecular Sizes, Sources of Chitosan and Plasticizer Types on Properties of Carboxymethyl Chitosan Films. Advanced Materials Research, 506, 611-614. 
Tantala, J., Rachtanapun, C., \& Rachtanapun, P. (2012b). Antimicrobial activity of chitosan and carboxymethyl chitosan from different types and sources of chitosan. Italian Journal of Food Science, 24(4), 97-101. https://doi.org/10.4028/www.scientific.net/AMR.506.611

Tapia, M. S., Rojas-Graü, M. A., Carmona, A., Rodríguez, F. J., Soliva-Fortuny, R., \& Martin-Belloso, O. (2008). Use of alginate- and gellan-based coatings for improving barrier, texture and nutritional properties of fresh-cut papaya. Food Hydrocolloids, 22(8), 1493-1503. https://doi.org/10.1016/j.foodhyd.2007.10.004

Vargas, M., Chiralt, A., Albors, A., \& González-Martinez, C. (2009). Effect of chitosan-based edible coatings applied by vacuum impregnation on quality preservation of fresh-cut carrot. Postharvest Biology and Technology, 51(2), 263-271. https://doi.org/10.1016/j.postharvbio.2008.07.019

Wang, Z., Zheng, L., Li, C., Zhang, D., Xiao, Y., Guan, G., \& Zhu, W. (2015). Modification of chitosan with monomethyl fumaric acid in an ionic liquid solution. Carbohydrate Polymers, 117, 973-979. https://doi.org/ 10.1016/j.carbpol.2014.10.021

\section{Copyrights}

Copyright for this article is retained by the author (s), with first publication rights granted to the journal.

This is an open-access article distributed under the terms and conditions of the Creative Commons Attribution license (http://creativecommons.org/licenses/by/4.0/). 